\title{
Coexistence of industry and agriculture for urban planning
}

\author{
E. Hanada ${ }^{1}$, T. H. Goh ${ }^{2}$, H. Gotoh ${ }^{3}$ \& M. Takezawa ${ }^{3}$ \\ ${ }^{1}$ Universiti Malaysia Sabah, Malaysia \\ ${ }^{2}$ Sab Tea Bhd, Malaysia \\ ${ }^{3}$ Nihon University, Japan
}

\begin{abstract}
Urban planning is an important national issue. It is both a technical and a political process concerned with controlling the use of land and designing the urban environment. Urban renewal can be incorporated into urban planning by adapting urban planning methods to existing cities in decline. We considered how industry and agriculture could coexist in urban plans in this paper.

Moringa fields have been in the spotlight all over the world recently. Moringa, native to parts of Africa and Asia, is the sole genus in the flowering plant family Moringaceae. Moringa grows quickly in many types of environments. Much of the plant is edible by humans or by farm animals. Feeding the high-protein leaves to cattle has shown to increase weight gain by up to $32 \%$ and milk production by 43 to $65 \%$. The seeds contain 30 to $40 \%$ oil that is high in oleic acid, while defatted meal is $61 \%$ protein. The defatted meal is a flocculant and can be used in water purification to settle out sediments and undesirable organisms. Moringa is being used as biodiesel in many developing countries. Three advantages of this source of biodiesel are that it is not in direct competition with food consumption, the high yield of Moringa trees allows it to be produced in large quantities, and its biodiesel has a better oxidative stability than other biodiesels. When the pods are harvested to produce biofuel, the trees keep on growing. If Moringa forests are planned and created in a country, refineries can be built nearby, so that country's economic growth can be expected. A plan for creating Moringa farming and forestry in cities and towns is described in this paper.
\end{abstract}

Keywords: urban planning, Moringa, farming, forest, biodiesel. 


\section{Introduction}

In recent years, global warming has become a world problem affecting many countries. Global warming is interlinked with climate change, as it is the rise in the average temperature of Earth's atmosphere and oceans since the late 19th century and this trend's projected continuation. Since the early 20th century, the Earth's mean surface temperature has increased by about $0.8^{\circ} \mathrm{C}\left(1.4^{\circ} \mathrm{F}\right)$, with about two-thirds of the increase occurring since 1980. Warming of the climate system is unequivocal, and scientists are more than $90 \%$ certain that it is primarily caused by increasing concentrations of greenhouse gases produced by human activities such as the burning of fossil fuels and deforestation. These findings are recognized by the national science academies of all major industrialized nations. Comprehensive, plan-based implementation of global warming countermeasures needs to be established, and the general public's understanding concerning the current situation of global warming must be deepened [1]. Urban, city, and town planning is a technical and political process concerned with the use of land and the design of the urban environment, including transportation networks, to guide and ensure the orderly development of settlements and communities. It concerns itself with research and analysis, strategic thinking, architecture, urban design, public consultation, policy recommendations, implementation, and management. Plans can take a variety of forms, including strategic plans, comprehensive plans, neighborhood plans, regulatory and incentive strategies, and historic preservation plans. Planners are often also responsible for enforcing the chosen policies. The modern origins of urban planning lie in the movement for urban reform that arose as a reaction against the disorder of the industrial city in the mid-19th century. Urban renewal can be incorporated into urban planning by adapting urban planning methods to existing cities suffering from decline. In the late 20th century, the term sustainable development has come to represent ideal outcomes as the sum of all planning goals. In the 1920s, the ideas of modernism began to surface in urban planning. Using new skyscraper-building techniques, the modernist city stood for the elimination of disorder, congestion, and the small scale, replacing them with preplanned and widely spaced freeways and tower blocks set within gardens. There were plans for large-scale rebuilding of cities in this era. Throughout the late 1940s and 1950s, housing shortages caused by wartime destruction led many cities to subsidize housing blocks. Planners used the opportunity to implement the modernist ideal of towers surrounded by gardens. The plan of the new town became a success, perhaps the only one of modern times, creating lively, intensive, and fully diversified cities [2].

\section{Coexistence of industry and agriculture}

The object of this study is to examine how industry and agriculture can coexist in land use. Industrial farming is a modern form of agriculture in which livestock, poultry, fish, and crops are produced on an industrial scale, using technoscientific, economic, and political methods. These methods may include 
innovation in agricultural machinery and farming methods, genetic technology, techniques for achieving economies of scale in production, the creation of new markets for consumption, the application of patent protection to genetic information, and global trade. Such practices are widespread in developed nations and increasingly prevalent worldwide. Most of the meat, dairy, eggs, fruits, and vegetables available in supermarkets are produced by industrial agriculture.

The birth of industrial agriculture more or less coincides with that of the Industrial Revolution in general. The discovery of vitamins and their role in animal nutrition in the first two decades of the 20th century led to vitamin supplements, which in the 1920s allowed certain livestock to be raised indoors, reducing their exposure to adverse natural elements. The discovery of antibiotics and vaccines facilitated raising livestock in concentrated, controlled animal feed operations by reducing diseases caused by crowding. Chemicals developed for use in World War II gave rise to synthetic pesticides. Developments in shipping networks and technology have made long-distance distribution of agricultural produce feasible. Agricultural production across the world doubled four times between 1820 and 1975, to feed a global population that grew from one billion human beings in 1800 to 6.5 billion in 2002. During the same period, the number of people involved in farming dropped as the process became more automated. There are several major challenges and issues faced by society with regard to industrial agriculture. Its benefits of cheap and plentiful food, convenience for consumers, contributions to nations' economies on many levels, from growers to harvesters and from processors to sellers must be maximized. Conversely, its downsides must be minimized. These include environmental and social costs, damage to fisheries, the necessity to clean up surface and groundwater polluted with animal waste, increased health risks from pesticides, increased ozone pollution from animals' methane production, and global warming from heavy use of fossil fuels. World population and the history of agriculture have grown dramatically: 30,000 years ago humans fed 6 million people with hunter-gatherer behavior, 3,000 years ago primitive agriculture fed 60 million people, 300 years ago intensive agriculture fed 600 million people, and today industrial agriculture is attempting to feed 6 billion people. Economic liabilities of industrial agriculture include its dependence on finite non-renewable fossil fuel energy resources as inputs to farm mechanization (equipment and machinery), for food processing and transportation, and as ingredients in agricultural chemicals. Future increases in energy prices are thus expected to result in increases in food prices. Therefore, there is a need to 'de-couple' non-renewable energy usage from agricultural production. Other liabilities include the peak phosphate issue, as finite phosphate reserves are currently a key input into chemical fertilizer for industrial agriculture. Industrial agriculture uses huge amounts of water, energy, and industrial chemicals, increasing pollution in arable land, usable water, and the atmosphere. Herbicides, insecticides, fertilizers, and animal waste products are accumulating in ground and surface waters. Agricultural production is highly dependent on bee pollination to pollinate many varieties of plants, fruits, and vegetables. 
Future increases in food commodity prices, driven by the energy price rises at peak oil use and the dependency of industrial agriculture on fossil fuels, are expected to lead to higher food prices, which particularly impact poor people. An example of this can be seen in the 2007-2008 world food price crisis. Food price increases have a disproportionate impact on the poor because they spend a large proportion of their income on food. The idea and practice of sustainable agriculture has arisen in response to the problems with industrial agriculture. Sustainable agriculture integrates three main goals: environmental stewardship, farm profitability, and prosperous farming communities. These goals have been defined by a variety of disciplines and may be looked at from the vantage point of the farmer or the consumer [3].

\section{Moringa farming and forestry}

Moringa is one of the world's most useful plants. It is a fast growing tree and is grown throughout the tropics for human food, livestock forage, medicine, dye, and water purification [4]. Moringa, native to parts of Africa and Asia, is the sole genus in the flowering plant family Moringaceae. Figure 1 shows the Moringa tree and Figure 2, the Moringa flower.

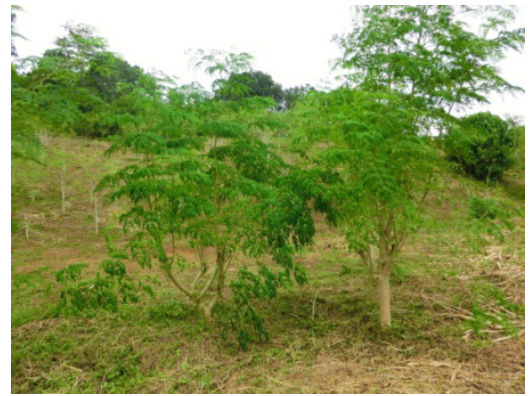

Figure 1: $\quad$ Moringa tree.

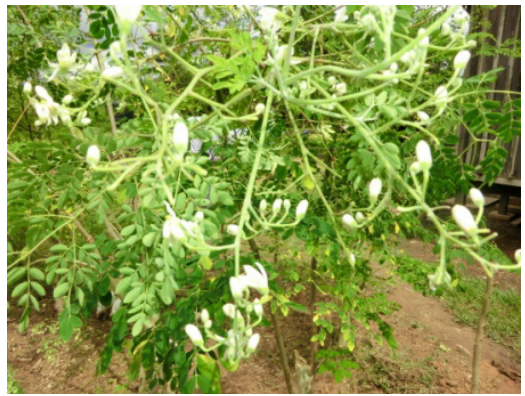

Figure 2: $\quad$ Moringa flower.

Moringa contains 13 species from tropical and subtropical climates that range in size from tiny herbs to massive trees. Moringa grows quickly in many environments, and much of the plant is edible by humans or by farm animals [5]. The Moringa plant is valued for its leaves and high-protein seeds, and it can also be made into defatted meal. The leaves are rich in protein, vitamin A, vitamin B, vitamin $\mathrm{C}$, and minerals: $100 \mathrm{~g}$ of fresh Moringa leaves include $8.3 \mathrm{~g}$ protein, $434 \mathrm{mg}$ calcium, $404 \mathrm{mg}$ potassium, $738 \mu \mathrm{g}$ vitamin A, and $164 \mathrm{mg}$ vitamin C. Feeding the high-protein leaves to cattle has been shown to increase weight gain by up to $32 \%$ and milk production by 43 to $65 \%$. The seeds contain 30 to $40 \%$ oil that is high in oleic acid, while defatted meal is $61 \%$ protein. The defatted meal is a flocculant and can be used in water purification to settle out sediments and undesirable organisms. Moringa cultivation is on the rise in Honduras and all across South America. There are claims that it is a profitable means of combating deforestation. As of 2012, support for Moringa farmers is being offered by the 
Honduran federal government through the Secretary of Agriculture and by private foreign investment firms. The plant's market potential is widespread given its easy growth and high nutrient content. Moringa oleifera silviculture is being promoted as a means to combat poverty and malnutrition. Moringa is being used to create biodiesel in many developing countries. The main advantages of this source of biodiesel are that it is not in direct competition with food consumption and has better oxidative stability than other bio-diesels, the trees continue growing after their pods are harvested to produce bio-fuel, and the high yield of Moringa trees allows it to be produced in large quantities [6].

\section{The case of Malaysia's Sabah state}

The South China Sea separates the two landmasses that make up Malaysia: one covering the southern half of the Maley Peninsula and the other spread over the northwestern coastal region of Bomeo (Sabah and Sarawak). Four fifths of the country is covered by forest and swampland. The Malaysia federal government has considerable power over the state government of the 11 states of Peninsular Malaysia. However, Sabah and Sarawak enjoy rights that the other states do not, rights which are derived from agreements reached when Malaysia was formed [7]. About two thirds of Malaysia is covered in forest, with some forests believed to be 130 million years old. The forest is dominated by dipterocarps. Low land forest occurs below $760 \mathrm{~m}$ and formerly East Malaysia was covered in such rainforest, which is supported by the hot wet climate. There are around 14,500 species of flowering plants and trees. Besides rainforests, there are over $1,425 \mathrm{~km}^{2}$ of mangroves in Malaysia, and a large amount of peat forest. There are an estimated 8,500 species of vascular plants in Peninsular Malaysia, with another 15,000 in the East. The forests of East Malaysia are estimated to be habitat of around 2,000 tree species, and are one of the most biodiverse areas in the world, with 240 different species of tree every hectare [8]. Sabah in Malaysia aims to make Moringa an industrial feature, producing various goods exploiting Moringa's benefits. Sabah is the easternmost of Malaysia's 13 member states and is located on the northern portion of the island of Borneo. It is the second largest state in the country after Sarawak, which borders it on its southwest. It also shares a border with the Indonesian province of East Kalimantan on the south. The western part of Sabah is generally mountainous, containing Malaysia's three highest mountains. The most prominent range is the Crocker Range, which houses several mountains varying in height from about 1,000 to $4,000 \mathrm{~m}$. Figure 3 is a map of Malaysia [8] and Figure 4 is the Sabah administrative divisions in the east Malaysia [9]. Sabah consists of five administrative divisions, which are in turn are divided into 25 districts [9]. The area and the population for each of the district is shown Table 1 [10]. 


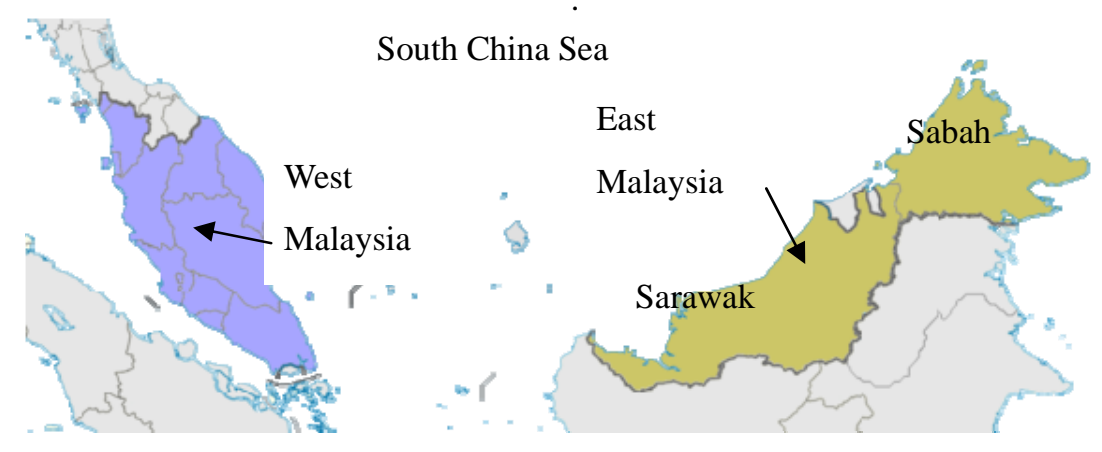

Figure 3: $\quad$ Map of Malaysia [8].

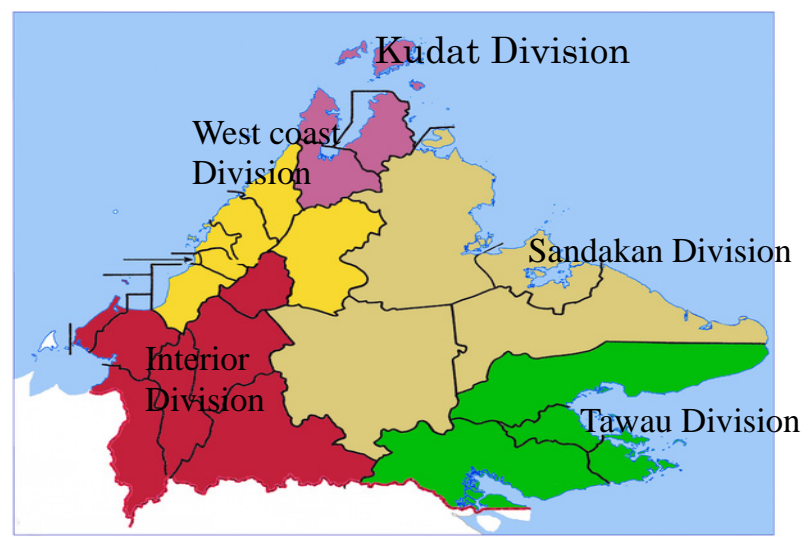

Figure 4: $\quad$ Sabah's administrative divisions [9].

Table 1: $\quad$ The area and the population for each of division (2010).

\begin{tabular}{|l|c|c|}
\hline Division & Area $\left(\mathrm{km}^{2}\right)$ & Population \\
\hline West coast division & 7,588 & $1,067,589$ \\
\hline Interior division & 18,298 & 424,534 \\
\hline Kudat division & 4,623 & 192,457 \\
\hline Sandakan division & 28,205 & 702,207 \\
\hline Tawau division & 14,905 & 819,955 \\
\hline
\end{tabular}

Kota Kinabaru is the capital of the state of Sabah, which is located in East Malaysia [10]. It is also the capital of the West coast division of Sabah. The city is located along the northwest coast of Borneo facing the South China Sea. Kota 
Kinabalu proper has a population of 452,058, while the larger urban area, which includes the Penampang district, has an estimated population of 628,725. Kota Kinabalu is a major fishing destination and a popular gateway for travelers visiting Sabah and Borneo. Kota Kinabalu is also one of the major industrial and commercial centers of East Malaysia. The National Park lies on the west of the Kota Kinabalu city and Mount Kinabalu is located towards the east. At a height of 4,095 m, Mount Kinabalu is the highest mountain in the Malay Archipelago and the 10th highest mountain in political Southeast Asia. The jungles of Sabah are classified as tropical rainforests and host a diverse array of plant and animal species. Kinabalu National Park was designated as a World Heritage Site in 2000 because of its richness in plant diversity combined with its unique geological, topographical, and climatic conditions. There are lower ranges of hills extending towards the western coast, southern plains, and the interior or central part of Sabah. These mountains and hills are traversed by an extensive network of river valleys and are in most cases covered with dense rainforest. The central and eastern portions of Sabah are generally lower mountain ranges and plains with occasional hills. Over three-quarters of the human population inhabit the coastal plains. Major towns and urban centers have sprouted along Sabah's coasts. The interior region remains sparsely populated with only villages and occasional small towns or townships. Beyond the coasts of Sabah lie a number of islands and coral reefs, including the largest island in Malaysia, Pulau Banggi. Sabah was traditionally heavily dependent on lumber, exported as tropical timber, but with natural forest depletion increasing at an alarming rate, ecological efforts to save the remaining natural rainforest areas began in early 1982, when forest conservation methods were employed, such as collecting seeds of different species, particularly Acacia mangium and planting them in pilot project areas pioneered by the researchers of Sandakan Forest Research Institute. However, palms for palm oil have emerged as a farmers' choice to plant as crops. Other agricultural products important in the Sabah economy include rubber and cacao. The agriculture sector is supported by the Department of Agriculture, the Ministry of Agriculture and Food Industry and the Palm Oil Industrial Cluster. There are hundreds of small and medium enterprises and industries in Sabah. Sabah's government is seriously pursuing industrialization with its Sabah Development Corridor plan, specifically in the Sepanggar area where the Kota Kinabalu Industrial Park and Sepanggar Container Port Terminal are located. Sabah manufacturing is supported by the Ministry of Industrial Development and the Department of Industrial Development and Research. In the 1970s, Sabah was ranked behind Selangor, which includes Kuala Lumpur, as the second richest state in Malaysia. As of 2010, Sabah is the poorest state in Malaysia. GDP growth was 2.4\%, the lowest in Malaysia behind Kelantan. The proportion of the population living below US\$1 per day declined from 30\% in 1990 to 20\% in 2009 but still lags behind other states that have lowered their poverty rates significantly from $17 \%$ in 1990 to $4 \%$ in 2009. Slums are nonexistent in Malaysia, but the highest number of squatter settlements is in Sabah, with 20,000 to 40,000 households. After Kuala Lumpur, the most low-cost public housing units under the People's Housing Program were built in Sabah. A cabotage 
policy imposed on Sabah and Sarawak is one of the reasons for the higher price of goods in those states. The rules, set in the early 1980s, made sure that all domestic transport of foreign goods between the peninsula and Sabah ports were to be carried by only Malaysian company vessels. This led to a shipping cartel charging excessive costs, ultimately leading to higher costs of living in East Malaysia. The cabotage rules also affected the industrial sector. The lack of industry providing jobs for professional and highly skilled workers has forced large numbers of Sabahans to seek opportunities in Peninsular Malaysia, Singapore, Australia, and the United States. The 5\% fixed oil royalty Sabah currently receives from Petronas according to the Petroleum Development Act of 1974 is also an issue of contention [10]. As part of Sabah area, Kota Kinabalu features a typical equatorial climate with constant temperatures, considerable amount of rain and high humidity. During the 1994-2004 period, Kotakinabalu's average temperature ranges from $20^{\circ} \mathrm{C}$ to $28^{\circ} \mathrm{C}$. The average annual rainfall is around 2,400 millimeters and varies markedly throughout the year. Kona Kitabalu is also the main industrial and commercial center for Sabah besides being the capital city. The economy is dominated by the primary sector of industry. Historically, the secondary sector dominated the economy, but due to rapid urbanization and economic development, this sector of the economy is slowly diminishing. More recently, a move towards a more tertiary-based industry has become more apparent, especially with regards to the boom in the tourism industry. Many state-level, national-level and international commercial banks, as well as some insurance companies have their headquarters or branches here. The project of Kota Kinabalu Industrial Park is currently being developed by the State Government of Sabah, Malaysia. The implememtation of the project is undertaken by Kota Kinabalu Industrial Park, Sdn Bhd, who is also responsible for the management of the park. The Kota Kinabalu Industrial Park occupying an area of 8,320 acres (about $35 \mathrm{~km}^{2}$ ) has been planned not just to meet the economic objective of facilitating growth but also to maximize utilization of its natural resources, namely its scenic coastline, its proximity to the port and the abundant source of raw materials. In addition, the development also fit into the overall scheme of a well-planned industrial estate that will be a model for the rest of Sabah. The development concept maximizes the site's potential to provide pleasant living and working environments based on environmentally sustainable development principles. This enhances the significance of the site and also establishes Kota Kinabalu and Sabah [11]. Land of Kota Kinabalu Industrial Park will be used as Industrial Area, Residential Area, Town Center and Commercial, Government and Institutions, Education and Community Facilities, Open Spaces and Landscape, Tourism and Recreational Park, Nature Park, Road, Railway and Public Utilities, Agricultural Area. Nature Park and Agricultural Area will be utilized as the planting acreage for Moringa increasing with multipurpose uses of protective foods, bio-diesel, fibers, medicines, etc. Figure 5 shows the Moringa seed bed and Figure 6, the Moringa farming developing in Sabah, Malaysia. 


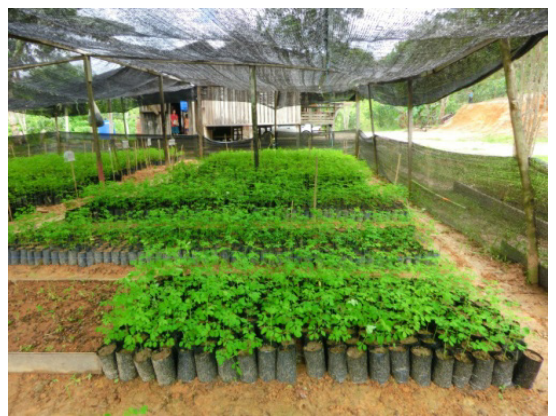

Figure 5: $\quad$ Moringa seed bed.

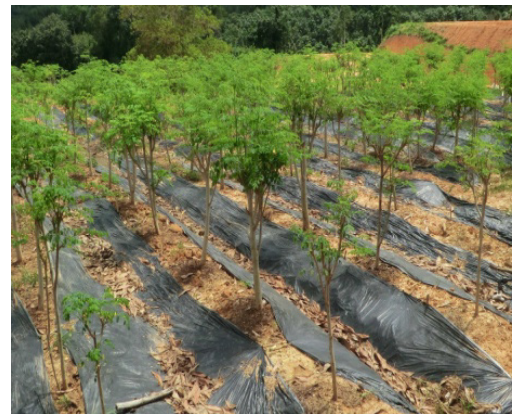

Figure 6: Moringa farming.

\section{Conclusions}

Recently, congestion in cities and global warming have become worldwide problems. Sustainable development and sustainability influence today's urban planners. Some planners argue that modern lifestyles use too many natural resources, polluting or destroying ecosystems, increasing social inequality, creating urban heat islands, and causing climate change. In order to combat these problems, many planners advocate sustainable cities. In the $21^{\text {st }}$ century, many countries have embarked on plans to build brand new, large cities. Many of these new cities are to be built using new technologies. Environmental protection and conservation are of utmost importance in many planning systems across the world. Not only are the specific effects of development to be mitigated, but also attempts are made to minimize the overall effect of development on the local and global environment. This is commonly done through an assessment of suitable urban infrastructure and microclimate. The idea and practice of sustainable agriculture has risen in response to the problem of industrial agriculture. Sustainable agriculture integrates three main goals: environmental stewardship, farm profitability, and prosperous farming communities. The Moringa tree has a high all-around utility value and grows very quickly, bearing fruit in less than 1 year and reaching $10 \mathrm{~m}$ high in 2 years. With this remarkable growth power, Moringa fruit can be harvested multiple times in a year very economically. Not only can it supply nutrient value, but Moringa can also be used as an organic fertilizer, and its carbon dioxide absorption factor, which is 50 times that of Cedar trees, has made it known as being good for the environment. Moringa farming and forestry are the best uses of industrial agriculture for urban planning because all parts of the Moringa tree are used - for food, oil, fiber, or medicine. The Moringa grows so fast as 5 meters a year, producing nourishing leaves and seeds which, by themselves, expand range of usage, such as for food, fodder, productivity improvement in agriculture, and so on. The powdered seeds after oil extraction which generates farm income, can be used as coagulant for purifying water. And the sediment after purification process is most suitable manure necessary for organic agriculture. Thus, there should be no other choice but to 
consider taking full advantages of Moringa. Assuming that global population is 100, while $75 \%$ people reserve food and have space to keep off the rain, $25 \%$ people do not. Besides, $17 \%$ people cannot drink clean and safe water. $5 \%$ people do not have food for tomorrow, suffering from starvation. In order to solve this issue, there should be no other suitable plant but Moringa [12]. Conventional city planning has been regarded as the maintenance of a population supported by social capital, but the problems of food and the environment, welfare, and medical care must be thought about at the same time in planning for the future, and the Moringa plant can play a role in solving all these problems.

\section{References}

[1] Wikipedia, the free encyclopedia, Global warming, http://en.wikipedia.org/wiki/Global_warming (2013/07/31)

[2] Wikipedia, the free encyclopedia. Urban planning, http://en.wikipedia.org/wiki/Urban_planning (2013/07/31)

[3] Wikipedia, the free encyclopedia, Industrial agriculture, http://en.wikipedia.org/wiki/Industrial_agriculture( 2013/08/05)

[4] Ameglo, N., How to Produce Moringa Leaves Efficiently, amagronewton@yahoo.com

[5] Wikipedia, the free encyclopedia, Moringa, http://en.wikipedia.org/wiki /Moringa(2013/06/23)

[6] Radovich, T., Farm and Forestry, http://agroforestry.net/scps (2013/08/05)

[7] Ministry of Land, Infrastructure, Transport and Tourism in Japan, An overview of spatial policy in Asian and European Countries, http:www.mlit.go.jp/kokudokeikaku/international/spw/general/Malaysia/in dex_e.html (2013/08/18)

[8] Wikipedia, the free encyclopedia, Malaysia, http://en.wikipedia.org/wiki /Malaysia (2013/07/30)

[9] Wikipedia, the free encyclopedia, Sabah, http://en.wikipedia.org/wiki /Sabah (2013/07/30)

[10] Wikipedia, the free encyclopedia, Kota Kinabalu, http://en.wikipedia.org /wiki/Kota_Kinabalu (2013/08/19)

[11] KKIP, Kota Kinabalu Industrial Park, http://www.sabah.com.my/kkip/ (2013/09/03)

[12] Japan Moringa Association, Future Activities, http://ksvu.or.jp/xoc /moringahp/e-keikaku.html (2013/08/24). 